\title{
English Phraseology: Integration with Terminology Science
}

\author{
Elena Nikulina \\ Moscow State Pedagogical University \\ Correspondence concerning this article should be addressed to Elena Nikulina, Moscow State Pedagogical \\ University, Institute of Philology and Foreign Languages, Prospect Vernadskogo, 88, Moscow, Russian \\ Federation,119571.E-mail: elenik40@yandex.ru
}

\begin{abstract}
The article is devoted to the study of English semi-idioms (a term suggested by A. Kunin), units with both terminological and metaphorical meanings. These units were studied from different angles but here their dual nature is viewed through the possibility of providing an experiment. The paper shows how a linguistic experiment can reveal not only the meaning of some unit, but the peoples' attitude towards the use of these phrases, their individual level of understanding, interpreting and realising. As cognition is very important in the understanding of semantics, as well as a new perspective in the study of phraseology, a synergetic approach as well as a cognitive one is becoming one of the ways to scrutinising the nature of terminological phraseological units. The paper focuses on the possible ways of showing that terms can develop metaphorical meanings though sometimes people have no ideas of the etymology of some units. An experiment to show the dual nature of such units as terminological phraseologisms was provided on the bases of a specially created questionnaire. The result of the experiment proved that some terms can acquire new metaphorical meanings and function in the language and speech as phraseological units. The results of the experiment as well as various references to the matter of the study - semi-idioms - may turn to be useful in language studies, learning English as a second language, investigating English Terminology and Phraseology.
\end{abstract}

Keywords: semi-idioms, terminological phraseological units, metaphor, meaning, experiment

It is well-known that the very term phraseology was suggested by Charles Bally who studied French Stylistics and regarded phraseology as a part of this science. Since his book "Precis de stylistique" (1905) was published and translated into various languages, a lot of research on phraseological units has been conducted.

In the Russian school of thoughts Academician V. Vinogradov described Phraseology in his book "The Russian Language" (1974). After that phraseological units were studied from the point of view of their semantics, structure, and complexity. Kunin (1970) wrote, " a phraseological unit is a stable combination of words with a fully or partially figurative meaning" (p. 210).

At the end of the 90s, cognitive study appeared. This new study actually is an interdisciplinary study of how the human perceives the process of learning and how the words are learned in the process of cognition. So, as a result, Phraseology became a new focus for those linguists who were keen on cognitive approaches. As Nacicsione (2010) puts it in her book, "Use of metaphor has been recognised as part and parcel of cognition, a revealing cognitive mechanism" (p. 17).

This paper is aimed at showing some modern approach in both English Terminology and English Phraseology as some units with a special meaning may undergo specific changes: they acquire a new metaphorical meaning and start to function in the language as phraseological units. The first linguist who pointed out some features of these dual units was Prof. A. Kunin (Russia, Moscow) who compiled the first English-Russian Phraseological Dictionary (1984) where along with phraseological units and phraseomatic units, the so-called semi-idioms were included and described. As Kunin put it in the preface of the dictionary, "semi-idioms have both literal and transferred meaning, the first meaning being usually terminological or professional and the second transferred" (Kunin, 1984, p. 14). The examples of these semi-idioms are as follows: a chain reaction - 
a chemical term and an idiom meaning a chain of quarrels, or to sail too close to the wind - a nautical term and an idiom meaning "to risk". There are many more examples of semi-idioms and I intend to reveal their nature by showing the results of the study and experiment provided on the basis of such units. In other words, a synergistic nature of the units under study is an object of the research.

It should be mentioned here that a term system does not

merely reflect a field of knowledge or activity but represents the theory behind it, so that two or more theories appear and present simultaneously in one and the same sphere (for example, in physics and linguistics). More than that, terminology is integrative: sometimes the terms of some sciences may function in various terminological systems, or even penetrate into the language for general Purposes (LGP) (Lejcik \& Nikulina, 2004, p. 14).

In case with semi-idioms a quite complicated process can be observed: the sphere of LSP (Language for Specific purpose) penetrates into LGP (Language for General Purposes) but being "modified" into the units with a metaphorical meaning.

\section{Materials and Methods}

The results of the research presented in this article come from the experiment provided in the USA with the help of interviews of people of different age, social status and gender. The experiment was based on the hypothesis that native speakers can not state for sure that one and the same word-combination can be both a term (a word with a special meaning and that is used in a special context) and an idiom. Along with the experiment, a number of other methods were used, such as synthesis and analysis, a method of phraseological identification, a method of contextual analysis as some contexts from literary works were used as well. It was very important to apply a method of statistics.

The results of the research show that the nature of the so-called semi-idioms, or terminological phraseological units (Nikulina, 2005, p. 3) is really complicated, and is worth being studied from various points of view. There were several steps in the analysis: firstly, a questionnaire was compiled which included some 33 semi-idioms taken at random from about 20 dictionaries, and a space to put a tick, whether this unit is a term, an idiom, or both; secondly, each participant had to put a word or phrase associated with a unit; thirdly, a method of statistical analysis was used.

\section{Results and Discussion}

\section{A Questionnaire}

According to Seliverstova, to the number of sciences, in which we use the experiment, there are primarily physics, chemistry, biology, and linguistics (Seliverstova, 1988, p. 432). An experiment in linguistics originates from the published works of Professor L. C. Shcherba, in 1933. Seliverstova and her students developed the theory of linguistic experiment, which is based on the method of verification of specific hypotheses by involving native speakers. Seliverstova indicated that, for the study of language "there should be a detailed system of quality views that would be the conceptual apparatus of the description...; language semantics is intended to reveal the picture of the world, reflected in the language" (Seliverstova, 1988, p. 431).

To solve the task of the so-called "identifying the semi-idiom", a questionnaire was developed, including 33 phrases, the sources of which was the terminology of military sphere, sports, physics, chemistry, botany and marine terms, terms of art and mathematics. In experiment teachers and students at the University of South Arkansas, North Dakota, Wisconsin, and Maryland (USA) took part. It is noteworthy that all semi-idioms and their definitions checked in various terminological and phraseological dictionaries so that for the author there was no doubt that the units under study have got both a terminological and metaphorical meaning.

\section{The Participants' Work}

A person who got the questionnaire had some 45 minutes to fill in the table. It was quite important to put the nationality, age, gender and occupation; the guidelines given in the questionnaire were as follows:

Read the word-combinations below. First, put any word that comes as an association with the word combination, then mark (x) in the appropriate column whether you consider the unit a term of some sphere of knowledge (chemistry, sports, culture, art, a military term, a nautical term, etc.) or just an idiom, or both.

So initially the table looked like this:

To prove that all the units which were selected for the analysis have both direct, literary, and indirect, metaphorical meaning here are some definitions from special dictionaries:

acid test: method of proving the worth, truth, etc. of something. (...) From chemistry. The original acid test was the testing of gold with nitric acid. If it was genuine and pure, it was unaffected; if false or mixed with other metals, these would corrode (Bloomsberry Dictionary of Idioms, 1990, p. 1), 
or:

dark horse: coll a person or thing whose true character or worth is unknown but may be better than is thought (...) referring to a horse in a race, whose ability to win races is unknown (Longman Dictionary of Idioms, 1992, p. 169),

or:

sail close to the wind: to break a rule of acceptable behaviour etc. (...) [Literary, in a sailing boat, to sail as nearly straight into the wind as possible] (The Wordsworth Dictionary of Idioms, 1996, p. 422).

So as it is shown, all the semi-idioms used for the analysis have a synergetic , dual nature: being initially a term, they may undergo some specific process of metaphorisation, thus acquiring a metaphorical meaning.

\section{Mathematical Approach}

One of the most important stages of the research was to count the answers and to analyse them from the point of view of statistics. Some observations were made as a lot of respondents just put down the phrase "?don't know" or just left the line not marked; there were commentaries, like "no sense" put to hardy annual and also ran, though the first one is claimed to be a medical term and the second one is from racing. Here are some diagrams that show the results of the experiment:
Table 1

Questionnaire (shortened)

\begin{tabular}{|c|c|c|}
\hline $\begin{array}{l}\text { Word- } \\
\text { combination }\end{array}$ & Association & Term \\
\hline
\end{tabular}

\begin{tabular}{l}
\hline 1. Acid test \\
\hline 2.Bear testimony \\
\hline 3. By and large \\
\hline $\begin{array}{l}\text { 4.Common } \\
\text { denominator }\end{array}$ \\
\hline 5. Dark horse \\
\hline 6. End product \\
\hline $\begin{array}{l}\text { 7.Inferiority } \\
\text { complex }\end{array}$ \\
\hline 8. Horse and \\
horse
\end{tabular}

\section{Quantum jump}

\section{Sail close}

to the wind

As it comes from this diagram, the most well-known semi-idioms turned to be a dark horse, also ran and neck or nothing, a terminological phraseological unit win by a neck was mostly stated as an idiom, though

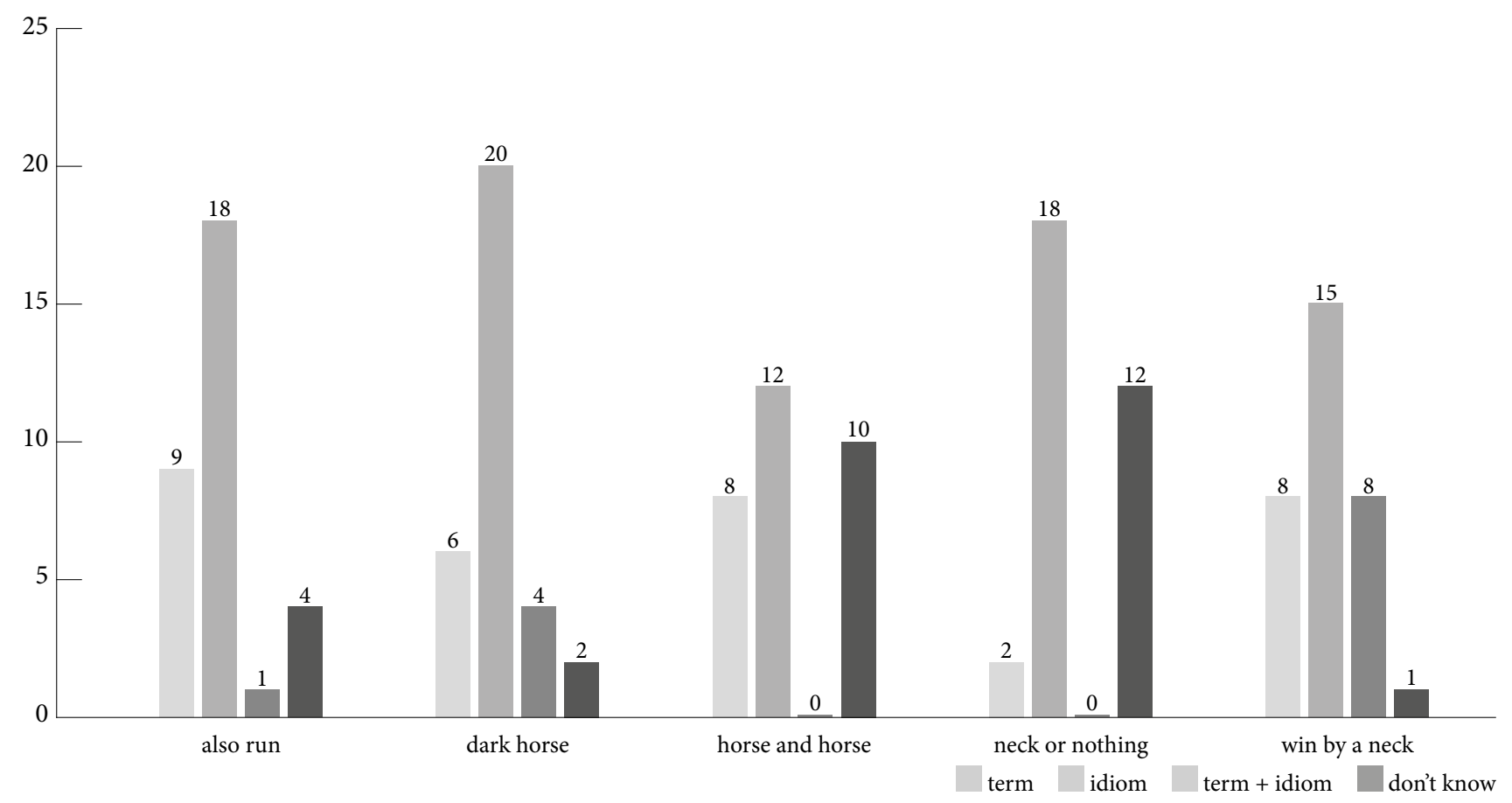

Figure 1. Analysis of the semi-idioms originated from sports. 


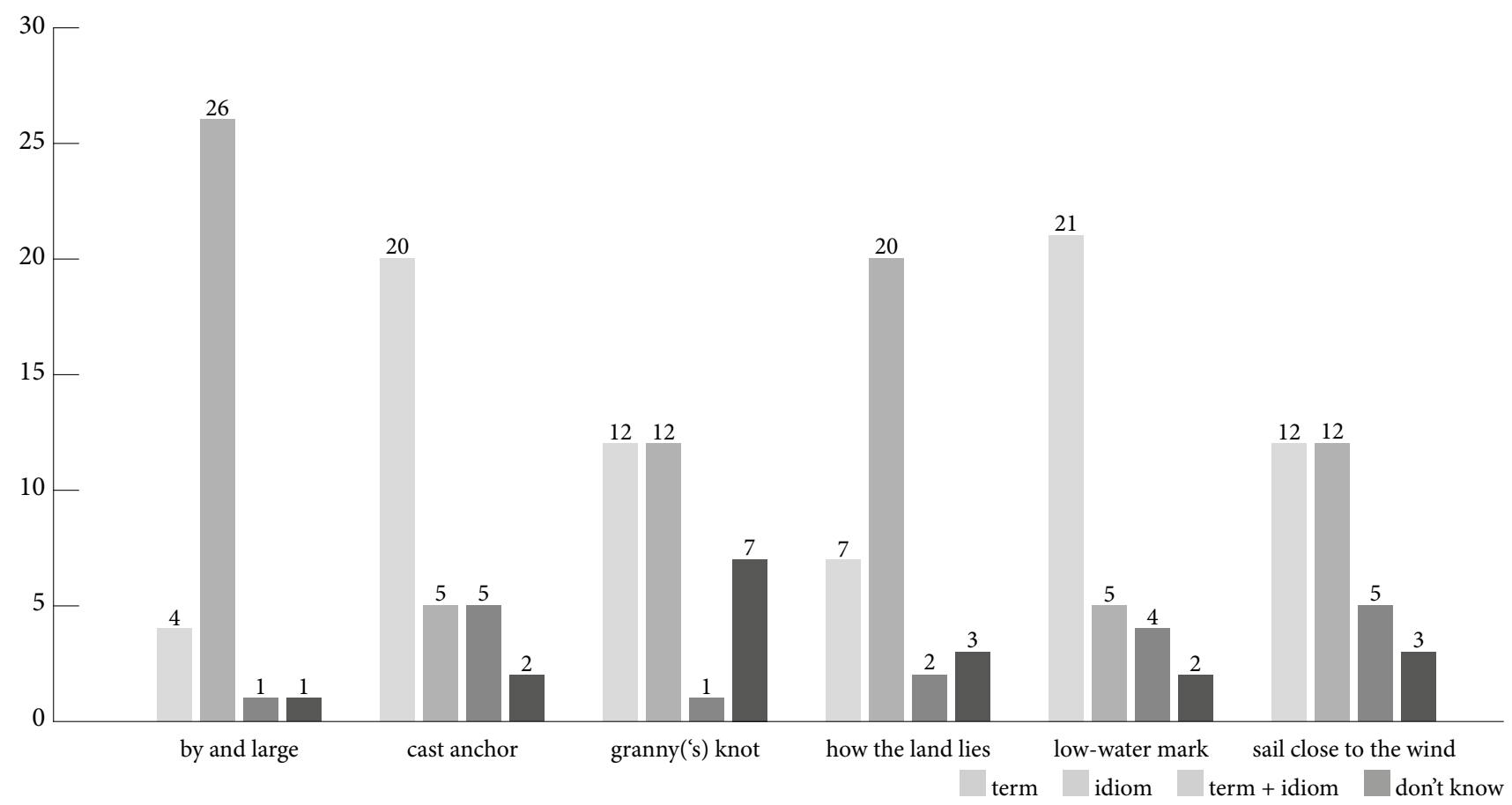

Figure 2. Analysis of the semi-idioms originated from marine terms.

an association came as "racing'. Once again it shows the dual form of the unit, though, probably not yet realised, or with the so-called "darkened semantics".

In Figure 2, the most important moment is that the semi-idiom by and large is marked as an idiom, though it is a nautical term, still used in various works, both literary and publicistic. To prove that dual nature of some units here are the contexts from fiction. Examples:

drop/cast/come (to) anchor

terminological use: On their way out, Garrett grabbed a raincoat from a peg near the door... "Give me a minute to drop the anchor," he said, "so we can eat without having to check the boat every few minutes." (N. Sparks, Message in a Bottle)

phraseological use: He came to anchor on the bed, and for a while sat picking at the coverlet in silence. (P. G. Wodehouse, “Right Ho, Jeeves!”);

So the first context is from a book where the owner of the boat knew a lot of marine terms and he uses the complex term "drop the anchor" in its direct, terminological meaning; the second contexts suggests the metaphorical usage as the main character just settles on the bed, preparing to sleep.

As it is clearly seen from the figure, the wordcombination cast (drop) anchor" was mostly recognised as a term and only five people stated this combination as an idiom or term+idiom.
However, the whole experiment just shows how people comprehend some idioms immediately: the units may not only originate from terms, but function as terms in the terminological sphere. As Kovecses puts in his book, "metaphor plays a role in human thought, understanding, and reasoning and, beyond that, in the creation of our social, cultural, and psychological reality" (Kovecses, 2009, p. xiii).

\section{Conclusion}

The results of the research presented in this article show clearly that one of the prospective ways to study linguistic phenomena is to study them in a combined way: semantics of some units may broaden and give way to some new meanings which, in their turn, would develop further and further combinations. On the other hand, it is important to underline that all registers are overlapping, they can disperse in various spheres giving way to such complicated units as semi-idioms. To study them is not only to enlarge one's vocabulary or to deepen one's knowledge, it is an opportunity to expose the laws of forming new words and phrases, to find universal features and to be able to trace the pattern of forming new meanings. A good tool to learn more about the language as well 
as cognition is to provide an experiment, to compare the results and to find out some peculiarities. It is also important the work of our brain to realise how the new associations and metaphors appear and overlap.

When conducting a linguistic experiment it becomes possible to explore the issue of inference - getting some output in the process of information processing, that is, to explore the terminological phraseological units from the cognitive point of view. Phraseology is the sphere for a more profound study and there are a lot of approaches to reveal the complicated nature of phraseological units. One of them was presented in the paper and the experiment contributes to a better understanding of our metaphorical competence. The perspective of studying the semantic peculiarities of semi-idioms is quite challenging and it may give way to new discoveries in the sphere of terminology and phraseology, their core and periphery.

\section{References}

Bally, Ch. (1905). Precis de stylistique. Geneve, Switzerland: Eggimann.

Jarvie, G. (2009). Bloomsberry dictionary of idioms. London, UK: A\&C Black.

Kirkpatrick, E. M, \& Schwarz, C. M. (Eds.). (1996). The Wordsworth dictionary of idioms. Wordsworth references. Hertfordshire, UK: Wordsworth Editions Ltd.
Kovecses, Z. (2010). Metaphor. Oxford, UK: Oxford Univerity Press.

Kunin, A. (1970). Anglijskaja frazeologija: Teoreticheskij kurs [English phraseology: A theoretical course]. Moscow, USSR: Vysshaya Shkola.

Kunin, A. (1984). Anglo-russkij frazeologicheskij slovar' [English-Russian phraseological dictionary]. Moscow, USSR: Russkiy Yazik.

Lejcik, V., \& Nikulina, E. (2003). The notion character in Russian terminology science. In M. Humar (Ed.), Collected papers from the Scientific conference terminology at the time of globalization (pp. 1115). Ljubljana, Slovenia: Narodna in Univerzitetna knjižnica.

Long, T. H. (1992). Longman dictionary of English idioms. Harlow, UK: Longman.

Naciscione, A. (2010). Stylistic use of phraseological units in discourse. Amsterdam, Netherlands: John Benjamins Publishing Company.

Nikulina,E.(2005).Anglo-russkij slovar'terminologizmov [English-Russian dictionary of terminologisms]. Moscow, Russia: Prometey.

Seliverstova, O., \& Suleimanova, O. (1988). Experiment in semantics. News of Academy of sciences. Series Literature and Language, LXVI(5), 431- 445.

Vinogradov, V. (1974). Russkij jazyk: Grammaticheskoe uchenie o slove [Russian language: Grammatical study of a word]. Moscow, USSR: Uchpedgiz.

White, J. G. (1998). Cambridge international dictionary of idioms. Cambridge, UK: Cambridge University Press. 